\title{
A Study on Non Executive Directors and Company Financial Performance : Evidence From India
}

Effulgence

Vol. 16 No. 1 (Special Issue 2)

January - June, 2018 Rukmini Devi Institute of Advanced Studies

E-mail : effulgence@rdias.ac.in, Website : www.rdias.ac.in

http://effulgence.rdias.ac.in/user/default.aspx

https:/ / dx.doi.org/10.33601/effulgence.rdias/v16/iSpl2/2018/149-158

\section{Ms. Vijay Lakshmi}

\begin{abstract}
The purpose of this study is to empirically examine the relationship between non-executive directors and Indian listed companies' performance. Since is known that board plays pivotal role into the organisation affairs and success, so their composition is equally important. With the outset of Securities exchange and board of India clause 49, Companies Act, 2013 numerous corporate governance practices have been mandated. And non-executive director are custodians of corporate governance matters and being responsible for questioning on various aspects of the organisation, developing strategy. This study took sample size BSE 200 companies' index listed in India for 8 years. Various statistical test has been employed in order to examine the impact between dependent and independent variable. The findings of the present study do not find any significant relationship between directors' composition and company performance.
\end{abstract}

Keywords: Corporate governance, Company performance, Government policy and regulation, Company performance. JEL Codes: G14, L25, G38, G39

\section{INTRODUCTION}

$\mathrm{I}$ $\mathrm{n}$ the recent times there has been an increased focus on the practices of the governance of the company especially due to major corporate collapses (e.g., enron, satyam, worldcom, hih, harris, etc) in USA, India and Australia. The demand for robust governance is witnessed by the numerous reforms and standards evolved at the country level and also at the international level (e.g., the Sarbanes-Oxley Act of USA, CLAERP 9 of Australia, Combined code of the UK and the Organisation for Economic
Development Code). The emphasis on corporate board of director's structure and executive compensation as a mechanism to corporate governance has always been a matter of considerable academic debate in both academic and empirical literature. Therefore an inspection into the aspects of corporate governance working being board as a major component will help to furnish relevant insights to bring changes in the governance structure of the developing economy like India. The corporate collapses resulting from a weak structure of corporate governance emphasised the need to refine and reform the governance system. Berkman, Zou \&

1. Ph.D Research Scholar, Department of Commerce, Delhi School of Economics, University of Delhi, vijaylakshmisahay@gmail.com 
Geng (2009) opined that firm's governance plays an essential part in probability of accounting frauds and the firms having weak governance are being more prone to accounting frauds. It was observed by Sun, Mellahi \& Liu (2011) that the failure to avert scams has raised many debates on efficiency of corporate governance rules, principles, procedures, structures and mechanisms. Shleifer \& Vishny (1997) says that the main aim of governance is to assure stockholders that managers are functioning best to achieve the shareholders' interests.

Lange \& Sahu (2008) says various facets of board leadership and its composition are precisely relevant in India in the light of given recent modifications in the legal structure highlights specifically for board structure requirement. There are evidences which shows that rules and institutional governance practices applicable in the developed nations are not apt to fit into emerging countries. Further, governance issues in Indian context about blend of ownership where the family-run businesses dominates. The features of family-owned business are prone to have distinct set of agency issues connected governance and company performance. Fama \& Jensen (1983) find that executive or internal directors, have an advantage position of having enough information and knowledge which will likely to give way to contrive with managers and thereby going against the shareholders' interests. In contrast, outside directors usually forms objective opinion, decisions, they act as supervisors and try best to eliminate the basic agency problem with the principal. Fama (1980) finds that non-executive directors functions as the "professional referees" in order to check on executive directors to stimulate their actions and also maximising shareholder value.

Different reforms were made in the 1990s and out of which most important is the development of Securities and exchange of India. The formation of the SEBI, which in turn resulted in the formation of four major committees (Bajaj committee in 1996, Birla committee in 2000, Chandra committee in 2002and the Narayanan Murthy committee in 2003)to review governance issues and to propose governance laws and reforms. The governance reforms, rules and suggestions as being promoted by these committees were formally executed by the SEBI like Clause 49 listing agreement authorization. It includes increasing the outside directors count in the board, to tackle duality issue, and to ensure of having persons with financial expertise. There also being some changes in the Clause 49 of the Listing agreement by the SEBI w.e.f. 1st January, 2006 calling limiting the number of directors on board. It is being predicted that these changes regarding composition and board working are means to raise governance standards which will help to improve performance of the company at large. The clause 49 of listing agreement has made it compulsory to have atleast half of the directors' to be non-executive and 1 woman director. And atleast on-third to independent when non-executives is not promoter or relative of promoter. A minimum of one-third directors are required to be independent when nonexecutive is not promoter or relative of promoter. Directors apart from independent directors, employees or nominees of the promoter's company are regarded as deemed relatives. SEBI has always kept better governance in its priority list. Corporate governance is seen upon as a hallmark and barometer in the corporate excellence profile. And it is apparent through regular updations and recommendations in relation to laws and regulations by SEBI in order to ensure accountability and to bring more clarity.

\section{REVIEW OF LITERATURE}

The relation composition of board and performance of the organisation has appealed the law makers in the past some years. The empirical and theoretical literature related to board composition and performance of the companies is examined in various empirical studies. Though it is seen that there is no sole theory that can tell the overall pattern of board composition and company performance. Nicholson \& Kiel, 2003 found that the nexus between director and company performance is diverse and 
complicated which can be guarded by any specific governance theory. By scrutinising the past literature, two theories of corporate governance are employed in present study. First one, agency theory which talks about the directors' role which they exercise by contributing in the performance of the companies they govern. It includes an examination of board leadership in relation to its effect on financial performance. Second is the resource dependency theory that talks about the nexus of the organisation and the relevant resources required to maximise the organisational performance. It also requires an audit of board size and activity. Numerous studies are done to evaluate empirically relationship between board composition and performance but results always shows diversity. Though as per agency theory saying that increased number of non-executives and independence is a relevant condition for superior working and the stewardship theory.

According to Kiel and Nicholson (2003) company and board size and inside directors are in positive relation with performance of the 348 listed Australian companies taken as sample study. Javed et al. (2013) observe in a study of banking sector of Pakistan between 2007 and 2011 that inclusion of non-executive director and presence of women director in the company shows a positive relation with company performance. Peng (2004) in a study of Chinese companies found that outside directors make a considerable difference in the performance and a bandwagon effect on the diffusion of appointing otside directors in the board of the company. Kamardin \& Haron (2011) using factor analysis by extracting 2 dimensions of monitoring function is management oversight and company performance where they found that non-executive and ownership is positively related with both dimensions. Ameer, Ramli \& Jakaria (2010) found that greater presentation of outside foreign directors are positively related with increased performance.

Contrary, there are evidences as found by Coles, McWilliams \& Sen 2001 found a negative relation relation with increased proportion outside directors and financial performance. Erickson, Park, Reising \& Shin (2005) found in dominant shareholder regime in Canada that there is a negative relation between outside directors and company performance. Kumar et al. (2012) found that there is a negative relationship between board composition and company performance in Indian study. Guo and Kga (2012) investigate the relation of 174 companies of Sri lanka in the year 2010 of Colombo stock exchange and found that company performance is negatively related with representation of non-executive directors. Even Kota \& Tomar (2010) that independent non-executive directors fail in the monitoring role assigned to them.

Though Hussein and Venkatram (2013) analyse the impact of variables of like board size, composition and board activity with the tobin $\mathrm{q}$ as a measure of company performance with a sample companies of 64 agri in Bombay stock exchange between 2007 and 2011 and found that larger board size is efficient in overseeing the management working resulting in reduced agency cost, while board meeting and their composition is not significantly related with the performance. Bhagat \& Black (1999) do not found any positive relation of board composition with increased profitability. Simultaneously, Lawrence \& Stapledon (1999) has studied directors' composition with the performance and remuneration of Australian companies and found no impact. Dalton, Daily, Ellstrand, and Johnson (1998), found no impact between board composition and performance incorporating moderator analyses by using company size, financial performance measure and board operational aspects of its composition. Yermack (1996) also do not found any significant relation between board composition and company performance. Consistent with this Hermalin \& Weisbach (1991) and Bhagat \& Bolton (2013) do not found any relation between composition of the board and company financial performance. Rashid, Zoysa, Lodh \& Rudkin (2010) examined the impact of outside independent directors' on economic performance in Bangladesh of 90 non-financial 
companies of Dhaka stock exchange for a period of 2005-2009 and found no relationship between outside directors' with company financial performance. So evidence from empirical and theoretical literature of past study are in contrast to arrive at any definite conclusion regarding the directors' composition on company financial performance.

\section{OBJECTIVE}

1. To review the studies relating to past literature and survey of board composition and performance of the company.

2. To empirically examine the relation between board composition and financial performance of the companies listed in India.

\section{HYPOTHESIS}

H0: There is no significant relation between board composition and company financial performance. H1: There is a significant relation between board composition and company financial performance.

\section{Data and Sample selection}

Data has been mainly drawn from secondary sources. Data was collected from the CMIE (centre for monitoring Indian economy) database and from companies annual report for a period of 8 years, that is, financial years 2008-2009 to 2015-2016. The sample of the present study consisted of companies listed on Bombay stock exchange (BSE) 200 index, having approximately $72 \%$ of the capitalisation. Financial companies and banks were not studied due to their different financial structure and are governed by The Banking Regulations Act, 1949. And also companies have been further excluded due to missing and unavailability of data.

\section{VARIABLE DESCRIPTION}

\section{DEPENDENT VARIABLES}

\begin{tabular}{|l|l|l|}
\hline Tobin Q & $\begin{array}{l}\text { This is measured by computing a } \\
\text { sum of market capitalisation of } \\
\text { equity divided to total assets }\end{array}$ & TQ \\
\hline $\begin{array}{l}\text { Return on capital } \\
\text { employed }\end{array}$ & $\begin{array}{l}\text { This measures the capital } \\
\text { employed return }\end{array}$ & ROCE \\
\hline Return on asset & $\begin{array}{l}\text { This measures the return on assets } \\
\text { of the company }\end{array}$ & ROA \\
\hline
\end{tabular}

\section{INDEPENDENT VARIABLE}

\begin{tabular}{|l|l|l|}
\hline Non- & This is measured by total & NED \\
executive & non-executive to total & \\
director & number of directors & \\
\hline
\end{tabular}




\section{CONTROL VARIABLES}

\begin{tabular}{|l|l|l|}
\hline Debt & It captured the debt amount in the company & DEBT \\
\hline $\begin{array}{l}\text { Company } \\
\text { age }\end{array}$ & $\begin{array}{l}\text { This measured by difference between observation } \\
\text { year and incorporation year and its natural log }\end{array}$ & COMP AGE \\
\hline $\begin{array}{l}\text { Market } \\
\text { capitalisation }\end{array}$ & $\begin{array}{l}\text { This is measured by the natural log of market } \\
\text { capitalisation }\end{array}$ & MKT CAP \\
\hline $\begin{array}{l}\text { Advertising } \\
\text { intensity }\end{array}$ & $\begin{array}{l}\text { This is measured by the ratio of advertising } \\
\text { expenses to sales }\end{array}$ & ADV INT \\
\hline $\begin{array}{l}\text { Research } \\
\text { intensity }\end{array}$ & $\begin{array}{l}\text { This is measured by the ratio of research } \\
\text { expenditure to sales }\end{array}$ & R D INT \\
\hline
\end{tabular}

\section{RESEARCH METHODOLOGY}

The study employed the panel data of 96 companies for a period of 8 years. The Descriptive Statistics and Pearson correlation analysis is conducted to interpret outcome linear dependence among the variables. Panel models provides benefits and benefit in relation to individual time series analysis andcrosssection data. Panel data allows for considerably more flexibility in the modelling of the behaviour of cross-sections than conventional time series (Greene, 2003). Secondly, the panel data structure enables analytical incorporation of significantly more observations (and more degrees if freedom) than would an analysis of individual times series. In panel data, the same cross-sectional unit is surveyed over time. In short, panel data have space and time dimensions (Gujrati, 2011). Panel data models allow us to construct and test more complicated behavioural models than purely cross-section or time-series data. This study has employed panel regression mode in order to examine the relation between directors' composition and different performance measures independently. Panel regression use two types regression models to study the relationship among variables namely, Random and fixed effects models. And hausman test is employed find which is preferred out of two (i.e., fixed effect or random effect model).
The following equation depicts the relationship between dependent and independent variable used in this study:-

$\mathrm{CP}_{\mathrm{it}}=\mathrm{a}_{\mathrm{i}}+\beta_{1} \mathrm{NED}_{\mathrm{it}}+\beta_{2} \mathrm{DEBT}_{\mathrm{it}}+\beta_{3} \mathrm{COMPAGE}_{\mathrm{it}}+$ $\beta_{4} \mathrm{MKT} \mathrm{CAP}_{\text {it }}+\beta_{5} \mathrm{ADV} \mathrm{INT}_{\text {it }}+\beta_{6} \mathrm{R} \& \mathrm{DINT}_{\mathrm{it}}+\mu_{\mathrm{it}}$

Where

$\mathrm{CP}_{\text {it }}=$ ROCE, ROA and Tobin $\mathrm{Q}$ as proxy for performance measuer for company $i$ in period $t$

$\mathrm{NED}_{\mathrm{it}}=$ Proportion of non-executive directors for company $i$ in period $t$

$\mathrm{DEBT}_{\text {it }}=$ Debt for company $\mathrm{i}$ in period $\mathrm{t}$

$\mathrm{COMPAGE}_{\mathrm{it}}=$ size of company as measured through company age for company $i$ in period $t$

MKT $\mathrm{CAP}_{\text {it }}=$ size of company as measured through market capitalisation sales for company $i$ in period $t$

ADV $\mathrm{INT}_{\mathrm{it}}=$ advertising expenses of the company $\mathrm{i}$ in period $t$

$\mathrm{R} \& \mathrm{D} \mathrm{INT}_{\mathrm{it}}=$ research and development expenses of company I in period $t$

$\mu=$ Disturbance term

\section{RESULTS AND ANALYSIS DESCRITIVE STATISTICS}

The table A1 depicts descriptive statistics of the dependent and independent variables of 768 observations (96 companies for 8 years). Board Composition (i.e., non-executive directors) has a 
mean .11 with value of minimum and maximum 0 and 0.93 repectively implying that companies under study on an average have $11.71 \%$ of non-executive on the board of directors'. Company performance shows a mean value of 0.053 with a minimum value and of -302.83 and max value 13.7856. The Accounting measures of performance ROCE has mean value of 12.72 with minimum value of -49.91 and maximum value of 60.9 and ROA has mean value of 8.764 with minimum value of -35.07 and maximum value of 37.53. The mean values of DEBT, COMP AGE, MKT CAP, ADV INT AND R \& D INT are $70127.64,1.527,5.083304,0.0995$ and 0.0138 respectively.

Table 1 (Descriptive Statistics)

\begin{tabular}{|l|l|l|l|l|l|}
\hline Variable & Observation & Mean & $\begin{array}{l}\text { Standard } \\
\text { deviation }\end{array}$ & Minimum & Maximum \\
\hline
\end{tabular}

\section{DEPENDENT VARIABLE}

\begin{tabular}{|l|c|c|c|c|c|}
\hline TQ & 768 & 0.053651 & 13.67979 & -302.8315 & 13.7856 \\
\hline ROCE & 768 & 12.72727 & 11.61959 & -49.91 & 60.9 \\
\hline ROA & 768 & 8.764076 & 7.685523 & -35.07 & 37.53 \\
\hline
\end{tabular}

INDEPENDENT VARIABLE

\begin{tabular}{|l|l|l|l|l|l|}
\hline NED & 768 & 0.11175 & 0.261931 & 0 & 0.9375 \\
\hline
\end{tabular}

\section{CONTROL VARIABLE}

\begin{tabular}{|l|c|c|c|c|c|}
\hline DEBT & 768 & 70127.64 & 149934.4 & 0 & 1082549 \\
\hline COMP AGE & 768 & 1.527568 & 0.2902014 & 0.30103 & 2.07555 \\
\hline MKT CAP & 768 & 5.089904 & 0.6273006 & 2.729141 & 6.77897 \\
\hline ADV INT & 768 & 0.099584 & 1.90067 & 0 & 50.7778 \\
\hline R\&D INT & 768 & 0.013837 & 0.0289995 & 0 & 0.19326 \\
\hline
\end{tabular}

Source - Research Result

The result of the correlation among the dependent variable and independent used in this studt as given in Table 2.

Table 2 (Correlation Matrix)

\begin{tabular}{|l|l|l|l|l|l|l|l|l|l|}
\hline & TQ & NED & DEBT & $\begin{array}{l}\text { COMP } \\
\text { AGE }\end{array}$ & $\begin{array}{l}\text { MKT } \\
\text { CAP }\end{array}$ & $\begin{array}{l}\text { ADV } \\
\text { INT }\end{array}$ & $\begin{array}{l}\text { R \& D } \\
\text { INT }\end{array}$ & ROA & $\begin{array}{l}\text { O } \\
\text { C } \\
\text { E }\end{array}$ \\
\hline TQ & 1 & & & & & & & & \\
\hline NED & 0.058 & 1 & & & & & & & \\
\hline DEBT & 0.0134 & 0.0488 & 1 & & & & & & \\
\hline $\begin{array}{l}\text { COM } \\
\text { P } \\
\text { AGE }\end{array}$ & 0.0235 & 0.0035 & 0.1136 & 1 & & & & & \\
\hline
\end{tabular}




\begin{tabular}{|l|l|l|l|l|l|l|l|l|l|}
\hline $\begin{array}{l}\text { MKT } \\
\text { CAP }\end{array}$ & 0.2647 & 0.0366 & 0.4064 & 0.1021 & 1 & & & & \\
\hline $\begin{array}{l}\text { ADV } \\
\text { INT }\end{array}$ & 0.0084 & -0.02 & -0.022 & -0.0703 & -0.021 & 1 & & & \\
\hline $\begin{array}{l}\text { R \& D } \\
\text { INT }\end{array}$ & 0.0003 & -0.055 & 0.1398 & 0.0044 & 0.0272 & -0.02 & 1 & & \\
\hline ROA & 0.0857 & 0.0763 & -0.2696 & -0.1246 & 0.1694 & -0.03 & 0.0661 & 1 & \\
\hline ROCE & 0.0875 & 0.047 & -0.2755 & -0.0907 & 0.1678 & -0.03 & 0.0188 & 0.96 & 1 \\
\hline
\end{tabular}

Source - Research Result

The test statistic developed by Hausman has an asymptotic $\chi^{2}$ distribution. If the null hypotheis is rejected, the conclusion is random effected(REM) or error components model (ECM) is not appropriate and that we are better by using FEM, in this case statisticak inferernces will be conditional on the $\varepsilon i$ in the sample(Gujrati, pg. 651).

In order to find out find which model is applicable out of two (that is, fixed or random effect) to examine relationship between the present study dependent variable and independent variable, the hausman test is conducted the results of which are shown in Table 3 with p-value of 0.4757 . Here the null hypothesis is accepted is accepted as the p-value is greater than 0.05 which says that random effect models is apt here to applied.

Table 3 (Hausman Test)

\begin{tabular}{|l|l|}
\hline Chi 2(5) & 4.53 \\
\hline Prob>chi2 & 0.4757 \\
\hline
\end{tabular}

Source - Research Outcome

As the per hausman test findings (given in Table 3), random effect estimation is used to examine the relation between board composition and company performance, and the findings of the result is presented in the Table 4. And the outcome of the random effect model to study the relationship between board composition and company performance (Tobin Q) as given in Table D4 depicts shows the $R$ squared value of 59.21 which means that $59.21 \%$ variance in the dependent variable is describe by the independent variable. The results further show that board composition and company performance as measured via Tobin $q$ th $p$ value of 0.800 , even the debt of the company and age of company has no significant association with tobin's q having $p$ value of 0.112 and 0.999 respectively. While the market capitalisation, advertising intensity and research \& development intensity is significant and positively related with Tobin $\mathrm{Q}$.

Table 4 (Test Results)

\begin{tabular}{|c|c|}
\hline & $(1)$ \\
\hline & TQ \\
\hline VARIABLES & 0.800 \\
\hline NED & 0.112 \\
\hline DEBT & 0.999 \\
\hline COMPAGE & 0.000 \\
\hline MKT CAP & 0.023 \\
\hline ADV INT & 0.042 \\
\hline R \& D INT & 0.682 \\
\hline Constant & 768 \\
\hline Observations & 59.21 \\
\hline R-squared & 96 \\
\hline $\begin{array}{l}\text { Number of } \\
\text { companies }\end{array}$ & \\
\hline
\end{tabular}

Source - Research Result

Next to study the relation between board composition and accounting measures of company performance (ROCE) the hausman test is conducted. And on the basis of the analysis as given in Table E5, it can be inferred from the result that null hypothesis cannot be accepted having $\mathrm{p}$ value $=0.0004$, stating that fixed effect model is apt. 
Table 5 (Hausman Test)

\begin{tabular}{|l|l|}
\hline Chi 2(5) & 22.7 \\
\hline Prob>chi2 & 0.0004 \\
\hline
\end{tabular}

\section{Source - Research Result}

Again the hausman test is conducted to study the relation between board composition and another accounting measure of company performance (ROA) as given in Table 6, and it can be inferred from the result that null hypothesis cannot be accepted having $\mathrm{p}$ value $=0.0159$, which means that the fixed effect model is appropriate.

Table 6 (Hausman Test)

\begin{tabular}{|l|l|}
\hline Chi 2(5) & 13.96 \\
\hline Prob>chi2 & 0.0159 \\
\hline
\end{tabular}

\section{Source - Research Result}

On the basis hausman test result (given in Table 5 and 6), fixed effect estimation model has been applied to study the relationship between board diversity and company performance namely ROCE, ROA and the result of which is given in Table 7. The results of the fixed effect model to study the relationship between board composition and company performance that is, ROCE, ROA as given in table 7 depicts that the value of $R$ squared is $44.12 \%, 52.38 \%$ respectively which means that the variance in dependent variable is explained by the independent variables collectively. The results further show that board composition as measured through non-executive directors has a significant and positive relationship with the company performance as measured through ROCE, ROA with $p$ value of 0.002 and 0.042 respectively, even the debt of the company has positive significant relation with both measures of performance and age of company has also no significant relationship with the Tobin $Q$ having $p$ value of 0.112 and 0.999 respectively. While the company age is positively related with ROCE and ROA, advertising intensity has significant relation with ROCE and no significant relation is found with ROA. And research \& development intensity is significantly and positively related with ROA and has no significant relation with ROCE.

Table 7 (Test Results)

\begin{tabular}{|c|c|c|}
\hline & $(2)$ & $(3)$ \\
\hline VARIABLES & ROCE & ROA \\
\hline NED & 0.002 & 0.042 \\
\hline DEBT & 0.000 & 0.028 \\
\hline COMPAGE & 0.000 & 0.001 \\
\hline MKT CAP & 0.250 & 0.000 \\
\hline ADV INT & 0.003 & 0.431 \\
\hline R \& D INT & 0.526 & 0.000 \\
\hline Constant & 0.682 & 0.260 \\
\hline Observations & 768 & 768 \\
\hline R-squared & 44.12 & 52.38 \\
\hline Number of & 96 & 96 \\
companies & & \\
\hline
\end{tabular}

Source - Research Result

\section{DICUSSION}

1. The result of the present study that is, board composition has no significant relation with market measure of performance (Tobin Q) are consistent with the past research work (Yermack, 1996; Hussein and Venkatram, 2013; Kota et al., 2010; Rashid A. et. al., 2010) and implying that may be outside directors cannot add potential economic value to the company. Therefore, it can be said from above analysis that the null hypothesis can be accepted

2. The findings of the current study finds a significant positive association between board's composition and performance measures, and are in line with the past work of Kamardin \& Haron (2011), Peng (2004). 


\section{CONCLUSIONS}

The main aim of this paper is to investigate one of the key facet of corporate governance which is the related to the connection between board composition and company performance in Indian listed companies. This research is guided by the Securities and Exchange Board of India's (SEBI) recommendation to address the threats concerned with corporate governance which though could possibly be turned into opportunities for prospective growth and opportunities if dealt with caution. This feature which is related to corporate governance is being identified as a necessary angle in the evolution of better governance in the company. The changing corporate governance landscape in India is of specific concern due to increased investments and business venture in order to meet the demands of blooming economy. The outcome of the present study can provide useful insights to stakeholders in their search to harmony among the in India aligning international standards as well. Although the mere requirement to have minimum board independence is not a remedy to the challenges of corporate governance until the demand to endorse an environment is created where outside directors can oversee and guide the actions of the controlling shareholders in true spirit.

\section{BIBLIOGRAPHY}

1. Abor, J., \& Biekpe, N. (2007).Corporate governance, ownership structure and performance of SMEs in Ghana: implications for financing opportunities. Corporate Governance: The international journal of business in society, 7(3), 288-300.

2. Agrawal, A., \& Knoeber, C. R. (1996). Firm performance and mechanisms to control agency problems between managers and shareholders. Journal of financial and quantitative analysis, 31(3), 377-397.

3. Ameer, R., Ramli, F., \& Zakaria, H. (2010). A new perspective on board composition and firm performance in an emerging market. Corporate
Governance: The international journal of business in society, 10(5), 647-661.

4. Bhagat, S., \& Black, B. (1999). The uncertain relationship between board composition and firm performance. The Business Lawyer, 921963.

5. Bhagat, S., \& Bolton, B. (2013). Director ownership, governance, and performance. Journal of financial and quantitative analysis, 48(1), 105-135.

6. Berkman, H., Zou, L., \& Geng, S. (2009). Corporate governance, profit manipulation and stock return. Journal of International Business and Economics, 9(2), 132-145.

7. Coles, J. W., McWilliams, V. B., \& Sen, N. (2001).An examination of the relationship of governance mechanisms to performance. Journal of management, 27(1), 23-50.

8. Dalton, D. R., Daily, C. M., Ellstrand, A. E., \& Johnson, J. L. (1998). Meta-analytic reviews of board composition, leadership structure, and financial performance. Strategic management journal, 19(3), 269-290.

9. Erickson, J., Park, Y. W., Reising, J., \& Shin, H. H. (2005). Board composition and firm value under concentrated ownership: the Canadian evidence, Pacific-Basin Finance Journal, 13(4), 387-410.

10. Fama, E. F., \& Jensen, M. C. (1983). Separation of ownership and control. The journal law and Economics, 26(2), 301-325.

11. Fama, E. F. (1980). Agency problems and the theory of the firm. Journal of political economy, 88(2), 288-307.

12. Guo, Z., \& Kga, U. K. (2012). Corporate governance and firm performance of listed firms in Sri Lanka. Procedia-Social and Behavioural Sciences, 40, 664-667.

13. Hermalin, B. E., \& Weisbach, M. S. (1991). The effects of board composition and direct incentives on firm performance. Financial management, 101-112.

14. Hussein, S. K., \& Venkatram, R. (2013). Corporate governance and firm's value: An empirical analysis of agri-input firms in India. International Journal of Commerce, Business 
and Management, 2(6), 353-362.

15. Jackling, B., \& Johl, S. (2009). Board structure and firm performance: Evidence from India's top companies. Corporate Governance: An International Review, 17(4), 492-509.

16. Javed, M., Saeed, R., Lodhi, R. N., \& Malik, Q. U. Z. (2013). The effect of board size and structure on firm financial performance: A case of banking sector in Pakistan. Middle-East Journal of Scientific Research, 15(2), 243-251.

17. Kamardin, H., \& Haron, H. (2011). Internal corporate governance and board performance in monitoring roles: Evidence from Malayasia. Journal of Financial Reporting and Accounting, 9(2), 119-140.

18. Kiel, G. C., \& Nicholson, G. J. (2007). Board composition and corporate performance: How the Australian experience informs contrasting theories of corporate governance. Corporate Governance: An International Review, 11(3), 189-205.

19. Kota, H. B., \& Tomar, S. (2010). Corporate governance practices in Indian firms. Journal of Management \& Organisation, 16(2), 266-279.

20. Kumar, N., \& Singh, J. P. (2012). Outside directors, corporate governance and firm performance: Empirical evidence from India. Asian Journal of Finance\& Accounting, 4(2), 39.

21. Lange, H., \& Sahu, C. (2008). Board structure and size: The impact of changes to Clause 49 in India. U21 Global Working Paper Series, No. 004/2008.

22. Lawrence, J., \& Stapledon, G. (1999). Is board composition important? A study of listed Australian companies.

23. Peng, M. W. (2004). Outside directors and firm performance during institutional transitions. Strategic management journal, 25(5), 453-471.

24. Sun, P., Mellahi, K \& Liu, G. S. (2011). Corporate governance failure and contingent political resources in transition economies: A longitudinal case study. Asia Pacific Journal of Management, 28(4), 853-879.

25. Shleifer, A., \& Vishny, R. W. (1997). A survey of corporate governance. The journal of finance,
52(2), 737-783.

26. Yermack, D. (1996). Higher market valuation of companies with a smaller board of directors. Journal of financial economics, 40(2), 185-211. 